\title{
Neonatal Holocarboxylase Synthetase Deficiency
}

National Cancer Institute

\section{Source}

National Cancer Institute. Neonatal Holocarboxylase Synthetase Deficiency. NCI

Thesaurus. Code C99247.

A rare autosomal recessive inherited disorder that is manifested in the neonatal period and is caused by mutations in the HLCS gene. It is characterized by deficiency of the enzyme holocarboxylase synthetase which facilitates the effective use of the vitamin biotin in the body. Signs and symptoms include difficulties in feeding and breathing, skin rash, seizures, lethargy, and coma. 